\title{
Review \\ Role of Clostridium perfringens Necrotic Enteritis B-like Toxin in Disease Pathogenesis
}

\author{
Kyung-Woo Lee ${ }^{1,2, * \mathbb{D}}$ and Hyun S. Lillehoj ${ }^{1}$ \\ 1 Animal Biosciences and Biotechnology Laboratory, Beltsville Agricultural Research Center, \\ Agricultural Research Service, USDA, Beltsville, MD 20705, USA; hyun.lillehoj@usda.gov \\ 2 Department of Animal Science and Technology, Konkuk University, Seoul 05029, Korea \\ * Correspondence: kyungwoolee@konkuk.ac.kr; Tel.: +82-2-450-0495
}

Citation: Lee, K.-W.; Lillehoj, H.S. Role of Clostridium perfringens

Necrotic Enteritis B-like Toxin in Disease Pathogenesis. Vaccines 2022, 10, 61. https://doi.org/10.3390/ vaccines10010061

Academic Editor: François Meurens

Received: 19 November 2021

Accepted: 29 December 2021

Published: 31 December 2021

Publisher's Note: MDPI stays neutral with regard to jurisdictional claims in published maps and institutional affiliations.

Copyright: (c) 2021 by the authors. Licensee MDPI, Basel, Switzerland. This article is an open access article distributed under the terms and conditions of the Creative Commons Attribution (CC BY) license (https:// creativecommons.org/licenses/by/ $4.0 /)$.

\begin{abstract}
Necrotic enteritis (NE) is a devastating enteric disease caused by Clostridium perfringens type $A / G$ that impacts the global poultry industry by compromising the performance, health, and welfare of chickens. Coccidiosis is a major contributing factor to NE. Although NE pathogenesis was believed to be facilitated by $\alpha$-toxin, a chromosome-encoded phospholipase $C$ enzyme, recent studies have indicated that NE B-like (NetB) toxin, a plasmid-encoded pore-forming heptameric protein, is the primary virulence factor. Since the discovery of NetB toxin, the occurrence of $\mathrm{NetB}^{+} \mathrm{C}$. perfringens strains has been increasingly reported in NE-afflicted poultry flocks globally. It is generally accepted that NetB toxin is the primary virulent factor in NE pathogenesis although scientific evidence is emerging that suggests other toxins contribute to NE. Because of the complex nature of the hostpathogen interaction in NE pathogenesis, the interaction of NetB with other potential virulent factors of $C$. perfringens needs better characterization. This short review will summarize the primary virulence factors involved in NE pathogenesis with an emphasis on NetB toxin, and a new detection method for large-scale field screening of NetB toxin in biological samples from NE-afflicted commercial broiler flocks.
\end{abstract}

Keywords: Clostridium perfringens; necrotic enteritis; NetB toxin; pathogenesis; NE detection; broiler chickens

\section{Introduction}

The world population is rapidly expanding and is expected to reach over nine billion people by the year 2050 [1]. Most of this population growth is expected to occur in Africa and Asia where the poultry industry will be required to sustainably meet the increasing demand for safer poultry meat and eggs. Thus, our role as animal scientists in combating world hunger is critical and there is a timely need to develop strategic priorities for sustainable food production systems. The global poultry industry is a dynamic industry that has successfully met an ever-increasing demand on global poultry meat and egg consumption. There are, however, ongoing challenges [2] to solve for sustainable poultry and eggs production. Those challenges include legislative bans on antibiotic use in animal feed, global climate change, and economically important disease outbreaks affecting the food industry, all of which could negatively affect optimum poultry performance. For example, it was estimated that a higher ambient temperature lowered the productivity and welfare of chickens resulting in an economic loss of USD128 to 165 million for the US poultry industry [3].

Over the last 50 years, sub-therapeutic doses of in-feed antibiotics have been a reliable tool to increase the welfare and productivity of chickens by controlling pathogenic bacteria and preventing dysbacteriosis. However, increasing concerns regarding the occurrence of antibiotic-resistant bacteria and drug residues in poultry meats halted the use of antibiotics in poultry feed globally. Finally, enteric disorders caused by Eimeria spp. or Clostridium perfringens, both of which are ubiquitous in the environment and gastrointestinal tract of 
animals, compromise the health, performance, and welfare of chickens. Coccidiosis caused by Eimeria spp. results in an economic loss of about 13 billion US dollars per year due to mortality and the use of in-feed anticoccidials [4]. Controlling enteric disorders is expected to be more challenging in the post-antibiotic era, and there is a timely need to develop novel solutions to promote the health and performance of chickens. Topics on gut health and alternatives to antibiotic use in chickens have been discussed elsewhere [2,5-10]. This review will focus on the devastating enteric disease that is mainly caused by avian-specific C. perfringens. Finding a sustainable solution to reduce economic losses caused by necrotic enteritis (NE) is a high priority for the global poultry industry as NE is a major challenge in antibiotic-free chicken production. This mini-review will summarize recent developments in understanding NE pathogenesis with an emphasis on the recently identified and putative principal virulence toxin, NE B-like (NetB) toxin. Future research directions to further understand NE pathogenesis will be briefly discussed.

\section{Necrotic Enteritis}

Necrotic enteritis (NE), an enteric disease in chickens caused by Clostridium perfringens type $A / G$, is a common disease that affects intensive broiler production globally. However, NE incidence has increased with the regulatory bans on in-feed antibiotics, which includes anticoccidials [11]. The reemergence of NE outbreaks in poultry production, especially in "No Antibiotics Ever (NAE)" poultry production operations, is increasingly prevalent. The NE causative agent, $C$. perfringens, is a ubiquitous bacterium in poultry housing and a common commensal in the chicken gastrointestinal tract [12]. NE often occurs in chickens between 2 and 6 weeks of age and mortality ranges from 2 to $50 \%$. The severity of $\mathrm{NE}$ is classified as either clinical or subclinical with afflicted flocks exhibiting symptoms ranging from increased mortality (i.e., clinical NE) to decreased feed intake (i.e., subclinical NE) $[13,14]$ in the afflicted flock. NE-afflicted chickens appear depressed and suffer from diarrhea with decreased performance, i.e., a low growth rate and feed intake with high feed conversion and uniformity. NE causes an acute enterotoxemia and the clinical signs last a short time, and often the only signs are a severe depression followed by a sudden increase in flock mortality [15]. Clinical NE is characterized by rapid death (less than $24 \mathrm{~h}$ ) once NE clinical signs develop [16]. Cholangiohepatitis is associated with subclinical NE and is detected at the slaughterhouse where the animal is condemned [17]. The gross lesions at necropsy are primarily found in the small intestines, which may be ballooned, friable, and may have brown blood-tinged fluid with a foul odor. The mucosa of an NE-infected animal is usually covered with a tan to yellow pseudo-membrane described as a "Turkish towel" [11] (Figure 1). NE-related liver condemnations at the slaughterhouse can be as great as $20 \%$ [18]. The cost of NE to the global broiler industry has been estimated to be from USD two billion [17] to six billion [19] and is likely to increase as the global animal agricultural industry expands.
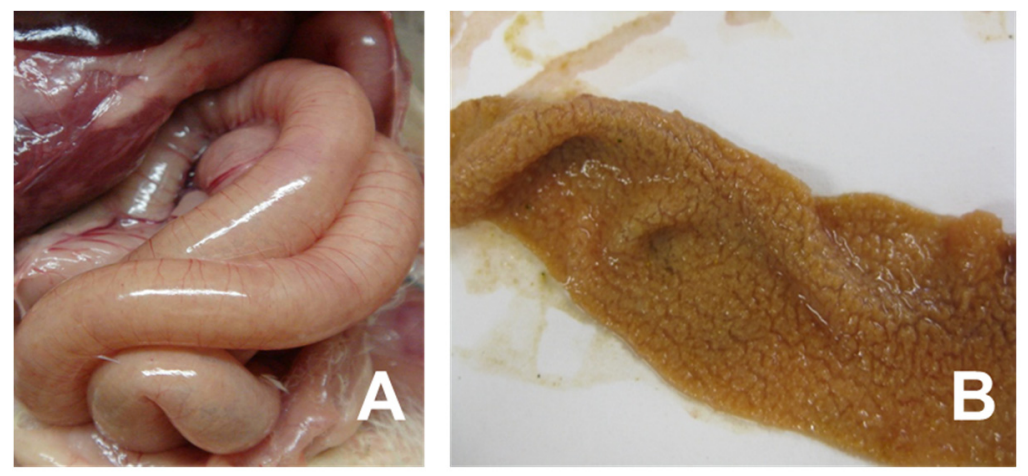

Figure 1. Clinical signs of necrotic enteritis in chickens. Panel (A) indicates small intestine showing friable, dilated and thin-walled filled with gas. Panel (B) shows jejunal/ileal mucosal exhibiting typical yellow pseudo-membrane, often called as Turkish towel appearance. 


\section{Clostridium perfringens Toxinotypes}

C. perfringens is anaerobic, non-motile, Gram-positive spore-forming bacteria found ubiquitously, including as a normal microbiota in animals, and produces at least 20 virulent toxins and enzymes [20,21]. C. perfringens is a fast-growing bacterium with an 8-12 $\mathrm{min}$ generation time when cultured at $43{ }^{\circ} \mathrm{C}$ in optimal media that extends to $12-17 \mathrm{~min}$ at $37^{\circ} \mathrm{C}$. Once dominantly colonized under optimal environments (e.g., predisposing factors), the fast-growing $C$. perfringens can cause a rapid onset of NE [22]. Six virulent factors (e.g., toxins/enzymes) have been used to designate the strains from $A$ to $G$ depending on their production capability for $\alpha$-toxin, $\beta$-toxin, $\varepsilon$-toxin, l-toxin, enterotoxin, and NE toxin beta-like (NetB) toxin [21] (Table 1), and their functions and production have been reported $[20,22,23]$. Initially, $C$. perfringens had five toxinotypes based on the chromosomal presence of $\alpha$-toxin, $\beta$-toxin, $\varepsilon$-toxin, or $\mathrm{l}$-toxin. However, the discovery of new toxin genes (e.g., enterotoxin and netB) and toxin-specific $C$. perfringens-mediated diseases has led to the classification of seven $C$. perfringens toxinotypes (Table 1). In the new toxinotyping scheme, $C$. perfringens type $F$ produces $\alpha$-toxin and enterotoxin but not $\beta$-toxin, $\varepsilon$-toxin, เ-toxin, or NetB toxin, and is an important enteric pathogen that causes food poisoning in humans [21,24]. This toxinotyping scheme emphasizes the role of enterotoxin production in C. perfringens-mediated food poisoning cases.

Table 1. Revised toxin-based classification of Clostridium perfringens.

\begin{tabular}{|c|c|c|c|c|c|c|}
\hline \multirow{2}{*}{ Type } & \multicolumn{6}{|c|}{ Toxin A Produced (Structural Gene) } \\
\hline & $\alpha$-Toxin $(c p a)$ & $\beta$-Toxin $(c p b)$ & $\varepsilon$-Toxin $(e t x)$ & l-Toxin (iap) & CPE (cpe) & NetB (netB) \\
\hline A & + & - & - & - & - & - \\
\hline B & + & + & + & - & - & - \\
\hline C & + & + & - & - & \pm & - \\
\hline $\mathrm{D}$ & + & - & + & - & \pm & - \\
\hline $\mathrm{E}$ & + & - & - & + & \pm & - \\
\hline $\mathrm{F}$ & + & - & - & - & + & - \\
\hline $\mathrm{G}$ & + & - & - & - & - & + \\
\hline
\end{tabular}

A Symbol (+) indicates the presence of the toxin and symbol (-) indicates the absence of the toxin.

All toxinotypes (i.e., type A to $G$ ) of $C$. perfringens can extracellularly secrete high levels of $\alpha$-toxin, which is encoded by the chromosomal plc gene (Table 1 ). $\alpha$-Toxin is a zincmetalloenzyme with a phospholipase C (plc) domain that is responsible for phospholipase, sphingomyelinase, and hemolytic activities [22]. Thus, $\alpha$-toxin has long been considered a major virulence factor in NE necrotic lesions. However, the recently discovered NetB toxin by $C$. perfringens is now proposed to be the primary toxin responsible for NE pathogenesis in broilers [25]. Accordingly, C. perfringens type $\mathrm{G}$ is responsible for NE in chickens as it has genes encoding the two typing toxins $\alpha$-toxin and NetB [21]. On the other hand, $C$. perfringens type $A$ can only produce $\alpha$-toxin, but not $\beta$-toxin, $\varepsilon$-toxin, 1 -toxin, enterotoxin, or NetB toxin. One exception to the seven toxinotype scheme is one reported case that showed the netB gene in $C$. perfringens type $C$, which was isolated from a subclinical NE case [26]. Nonetheless, the netB gene is only detected in C. perfringens type G strains.

\section{C. perfringens Toxins}

C. perfringens proliferation inside the host requires the degradation of host tissues as it lacks many genes related to amino acid biosynthesis. Thus, the ability of $C$. perfringens to obtain essential nutrients for survival and growth depends on the many toxins and enzymes it produces. In addition to $\alpha$-toxin and NetB toxin, $C$. perfringens type $G$ also produces more than 20 toxins and enzymes that are responsible for NE pathogenesis (Table 2). C. perfringens type A/G has chromosome- or plasmid-borne genes that encode for $\alpha$-toxin, 
perfringolysin $\mathrm{O}$, collagenases, sialidases, hyaluronidases, collagen adhesion protein, NetB toxin, beta2 toxin, and TpeL toxin. These toxins and enzymes are currently recognized as being important, but more NE virulence factors are likely to be discovered [21].

C. perfringens toxins can be grouped into four categories [27] depending on their activities: (a) membrane damaging enzymes, (b) pore-forming toxins, (c) intracellular toxins, and (d) hydrolytic enzymes. Membrane damaging toxins such as $\alpha$-toxin mainly damage the target cell membranes via their ability to hydrolyze host cell membrane constituents. The $\alpha$-toxin $(43 \mathrm{kDa})$, encoded by chromosome-borne plc gene, is 37 amino acid residues long with two domains, the $\mathrm{N}$-terminal catalytic domain and the $\mathrm{C}$-terminal membranebinding domain [28]. Its mechanism of action is complex, requiring lipid hydrolysis (e.g., phosphatidylcholine and sphingomyelin) and plasma membrane binding via the TrkA receptor, which triggers a signal transduction pathway [29]. Synergistic interactions between $\alpha$-toxin and sialidases secreted by C. perfringens have also been reported [29].

Table 2. Properties of Clostridium perfringens toxins.

\begin{tabular}{|c|c|c|c|c|c|c|}
\hline Full Name & Gene & Other Name & Gene Location ${ }^{A}$ & Size (kDa) & Activity & References \\
\hline Alpha-toxin & cpa, plc & phospholipase C & $\mathrm{C}$ & 43 & $\begin{array}{l}\text { To hydrolyze cell membrane } \\
\text { phospholipids }\end{array}$ & [22] \\
\hline Perfringolysin $\mathrm{O}$ & pfoA & $\begin{array}{l}\theta \text {-toxin } \\
\text { (pore-forming } \\
\text { toxin) }\end{array}$ & $\mathrm{C}$ & 54 & $\begin{array}{l}\text { Pore formation via binding to } \\
\text { cholesterol-comprising cell } \\
\text { membrane }\end{array}$ & {$[22,30]$} \\
\hline Collagenase & colA & $\mathrm{k}$-toxin & $\mathrm{C}$ & 120 & $\begin{array}{l}\text { To degrade collagen that is main } \\
\text { component of connective tissues } \\
\text { of the host cells }\end{array}$ & {$[22,31]$} \\
\hline Sialidase & nanI & $\begin{array}{l}\text { secreted major } \\
\text { neuramidases }\end{array}$ & $\mathrm{C}$ & 77 & \multirow{3}{*}{$\begin{array}{l}\text { Involved in removal of sialic acids } \\
\text { from a variety of glycoconjugates } \\
\text { on cell membranes }\end{array}$} & \multirow{3}{*}{ [32-34] } \\
\hline Sialidase & nanH & $\begin{array}{l}\text { non-secreted } \\
\text { neuramidases }\end{array}$ & $\mathrm{C}$ & 43 & & \\
\hline Sialidase & nanJ & $\begin{array}{c}\text { secreted } \\
\text { neuramidases }\end{array}$ & $\mathrm{C}$ & 129 & & \\
\hline Hyaluronidase & nagH & $\mu$-toxin & $\mathrm{C}$ & $\approx 182$ & \multirow{5}{*}{$\begin{array}{l}\text { To degrade hyaluronan coating } \\
\text { cells allowing direct contact } \\
\text { between pathogen and host cells, } \\
\text { or to degrade hyaluronan leading } \\
\text { to viscosity reduction facilitating } \\
\text { increased permeability of the } \\
\text { connective tissues }\end{array}$} & \multirow{5}{*}[35,36]{} \\
\hline Hyaluronidase & nagI & $\mu$-toxin & $\mathrm{C}$ & $\approx 146$ & & \\
\hline Hyaluronidase & nagJ & $\mu$-toxin & $\mathrm{C}$ & $\approx 128$ & & \\
\hline Hyaluronidase & nagK & $\mu$-toxin & $\mathrm{C}$ & $\approx 131$ & & \\
\hline Hyaluronidase & nagL & $\mu$-toxin & $\mathrm{C}$ & $\approx 127$ & & \\
\hline $\begin{array}{l}\text { Collagen adhesion } \\
\text { protein }\end{array}$ & cnaA & cell surface protein & $\mathrm{C}$ & 78 & $\begin{array}{l}\text { Binding of the Clostridium } \\
\text { perfringens to collagen types IV, } \mathrm{V} \\
\text { and gelatin }\end{array}$ & [37] \\
\hline NE B-like toxin & netB & pore-forming toxin & $\mathrm{P}$ & 33 & $\begin{array}{l}\text { To form heptameric, hydrophilic } \\
\text { pores with a central diameter of } \\
\text { approximately } 26 \AA\end{array}$ & {$[38,39]$} \\
\hline Beta2 toxin & cpb2 & pore-forming toxin & $\mathrm{P}$ & 28 & $\begin{array}{l}\text { Pore forming leading to cell } \\
\text { disruption }\end{array}$ & {$[40]$} \\
\hline $\begin{array}{l}\text { Toxin C. perfringens } \\
\text { large cytotoxin }\end{array}$ & tpeL & $\begin{array}{l}\text { large clostridial } \\
\text { toxin }\end{array}$ & $\mathrm{P}$ & $\approx 205$ & $\begin{array}{l}\text { Ras-specific glucosyltransferase } \\
\text { activity inactivating the Ras } \\
\text { signaling pathway leading to } \\
\text { apoptosis }\end{array}$ & [41-43] \\
\hline
\end{tabular}

${ }^{\text {A }} \mathrm{C}=$ chromosome; $\mathrm{P}=$ plasmid.

The pore-forming toxins is the largest class of bacterial protein toxins and includes perfringolysin $\mathrm{O}, \mathrm{NetB}$ toxin, beta2 toxin, and enterotoxin. As the name indicates, poreforming toxins can form either small or large pores through the membrane, a common mechanism of cell death. Perfringolysin $\mathrm{O}$ (or $\theta$-toxin) is known to form pores by binding to cholesterol in the lipid bilayer of the membrane while enterotoxin is mediated by binding to claudin [30]. However, neither the NetB nor beta2-toxin receptors are known [30]. NetB is known to be a major virulence toxin in NE-afflicted chickens [39], but the role of beta2 toxin in chicken NE is controversial [44,45]. However, C. perfringens harboring $c p b 2$ gene has been known to play a role in C. perfringens-associated enteritis in piglets [46]. 
The third class is intracellular toxins that are internalized into host cells to disrupt the cellular cytoskeleton [27]. Those NE virulence candidates include the TpeL toxin, which is a member of the large clostridial toxin family. The TpeL toxin is proposed to potentiate the NE pathogenesis by C. perfringens type A/G strains [47]. TpeL has several domains that exhibit glycosyltransferase activity, autocatalytic activity, and a transmembrane domain that delivers the glycosyltransferase enzyme into the cytosol of host cells [41]. TpeL selfmediates host cell entry and mono-glycosylates Ras proteins, thus inhibiting Ras signaling and inducing cell apoptosis [43]. Gu et al. reported that five out of 19 netB-positive C. perfringens isolates from NE-afflicted chickens were also positive for tpeL and exhibited differing patterns of in vitro TpeL production [47]. Coursodon et al. showed that chickens infected with TpeL-positive $C$. perfringens exhibited a more rapid development of NE with a higher NE-associated mortality rate than those challenged with TpeL-negative C. perfringens [42]. These finding suggests that the TpeL toxin can potentiate the virulence effect of NE-inducible C. perfringens strains [42].

Finally, hydrolytic enzymes degrade or hydrolyze substrates associated with the surface of the host cells and include both polysaccharide-degrading enzymes (e.g., sialidases and hyaluronidases) and proteinases (e.g., collagenases). Collagens and hyaluronic acids are the predominant fibrous proteins composing the extracellular matrix. Sialic acid-containing glycoconjugates cover the outer surface of the cytoplasmic membrane, some participate in connecting to the extracellular matrix components or in cell-cell interactions [48]. Hydrolytic toxins are believed to function as virulence factors that aid C. perfringens proliferation and spread in infected tissues and possibly potentiate other toxins by facilitating their diffusion [48]. The C. perfringens genome encodes five hyaluronidase genes designated as nagH, nagI, nagJ, nagK, and nagL (Table 2) [35]. Sialidases (or neuraminidases) function to degrade sialic acids from glycoconjugates found throughout the body and making them available as nutrients to C. perfringens [34,49]. C. perfringens produces three different sialidases (designated NanH, NanI and NanJ) with NanI and NanJ being extracellularly secreted. The non-secreted NanH acts on partially degraded carbohydrate polymers that are transported into the bacterial cells. Trypsin can enhance the activity of NanI but not NanH or NanJ [49]. Collagenase (or kappa toxin), encoded by $\operatorname{col} A$, is a primary $C$. perfringens toxin that degrades collagen, an integral component of the host connective tissues and basal membranes. Collagen disruption by collagenase may lead to the loss of tissue integrity and subsequent tissue necrosis [36]. Findings that collagenase activity was increased in the intestinal tissue of broilers challenged with C. perfringens may suggest its involvement as a virulent factor in the initial stages of NE [50].

In addition to the toxins and enzymes that we discussed above, collagen adhesion protein, encoded by cnaA, has recently been reported in NE-producing C. perfringens strains [37]. C. perfringens strains harboring cnaA were all virulent and bound to collagen type $\mathrm{IV}, \mathrm{V}$, and gelatin in vitro. In a follow-up study by Wade et al., cnaA-deleted C. perfringens lost the ability to bind to collagen in vitro, did not induce NE lesions in vivo, and showed a reduced ability to colonize on the ileal mucosa in vivo [51]. These results show the importance of C. perfringens adherence to extracellular matrix proteins as a crucial virulence factor in $\mathrm{NE}$ pathogenesis [51].

\section{C. perfringens NetB Toxin and Its Role in NE}

Recent molecular and proteomic studies have increased our understanding of the structure and function of NetB in NE pathogenesis [33,38,52-54]. The netB gene is encoded in the $42-\mathrm{kb}$ NELoc-1 region on an ca. $85-\mathrm{kb}$ plasmid [55]. NetB toxin production is tightly controlled and regulated by the VirR/VirS two-component signal system [23] and an accessory agr-like quorum sensing system [54] located on the $C$. perfringens chromosome. NetB is secreted as 33-kDa $\beta$-barrel toxin that forms 1.6- to 1.8-nm pores in susceptible cells. It shares some structural similarity (less than $40 \%$ ) with $\beta$-toxin from C. perfringens, $\alpha$ hemolysin, $\gamma$-toxin, and leukocidin from Staphylococcus aureus, and cytotoxin $\mathrm{K}$ from Bacillus cereus $[25,39]$. The NetB toxin is cytotoxic against the chicken leghorn male hepatoma 
cell line (LMH) but did not affect the viability of chicken embryo fibroblast cells (DF1) or a chicken macrophage cell line (HDll) [39]. Keyburn et al. clearly showed that the NetB toxin, but not alpha toxin, is an essential virulence factor for NE in broiler chickens using plc- and netB-deletion mutants of the virulent $C$. perfringens EHE-NE18 strain $[39,56]$. Furthermore, Coursodon et al. reported that a plc-deletion mutant of the virulent $C$. perfringens JGS4143 strain induced NE in chickens [57]. However, the latter also detected $\alpha$-toxin in chickens challenged with the plc-deletion mutant. In addition, Zhou et al. developed a $C$. perfringens strain missing the NELoc-1 virulence plasmid from the virulent $C$. perfringens $C P 1$ strain, which was then complemented with net $B$. While the virulent $C$. perfringens strain $\mathrm{CP} 1$ induced NE, the $\mathrm{CP} 1$ strain missing the NELoc-1-encoding plasmid did not [58]. However, complementing the netB-deficient $\mathrm{CP} 1$ variant strain with $n e t B$ gene restored its intermediate virulence. Collectively, these studies $[39,56-58]$ proved that other virulence factors on the NELoc-1 plasmid or elsewhere, are required for NE in addition to $\alpha$-toxin and NetB since NE disease has been induced in broiler with both netB-positive and -negative $C$. perfringens isolates.

The molecular-based detection of netB-positive C. perfringens isolates in NE-afflicted broiler flocks has been reported over the last decade (Table 3) [59-65]. A summary of the most frequently studied virulent NE-causing strains globally highlights the importance of net $B^{+}$ C. perfringens for experimentally reproducible NE models (Table 3 ). In contrast, findings on the presence of netB-positive $C$. perfringens strains in healthy chickens $[60-62,64,66,67]$, the recovery of netB-negative strains from NE-afflicted chickens [59-61,63,67,68], and successful NE reproduction by net $B$-negative $C$. perfringens $[39,68,69]$ indicate the role of additional virulence factors in NE pathogenesis.

There is limited understanding of NE pathogenesis in the field although C. perfringens overgrowth often causes the simultaneous and dynamic development of NE lesions in chickens susceptible to NE [70-72]. Barbara et al. reported that NE-causing C. perfringens are the dominant colonizer in the chicken gut compared to non-NE-causing strains due to the secretion of inhibitory antimicrobial bacteriocins and/or toxins [73]. Necrotic lesions caused by netB-positive $C$. perfringens start at the basal membrane and lateral segments of the enterocytes then spreads to the entire lamina propria [71,72]. In addition, the gut integrity is weakened by hydrolytic enzymes including collagenases, sialidases, and hyaluronidases while cell surface $C$. perfringens proteins facilitate its binding to the damaged intestinal mucosa, leading to severe NE lesions [70,74].

Table 3. NE strains often used in experimental NE studies.

\begin{tabular}{|c|c|c|c|c|c|c|c|c|}
\hline \multirow{2}{*}{ Strain } & \multirow{2}{*}{ Country } & \multirow{2}{*}{ Status } & \multicolumn{5}{|c|}{ Virulent Genes } & \multirow{2}{*}{ References } \\
\hline & & & Plc & NetB & CnaA & TpeL & $\mathrm{Cpb2}$ & \\
\hline Del1 & USA & $\mathrm{NE}^{\mathrm{A}}$ & + & + & + & - & + & {$[47,68]$} \\
\hline TpeL17 & USA & $\mathrm{NE}$ & + & + & na ${ }^{B}$ & + & + & [47] \\
\hline N11 & USA & Health & + & - & - & - & + & {$[68,75]$} \\
\hline CP15 & USA & NE & + & - & - & - & - & {$[68,75]$} \\
\hline JGS4143 & USA & NE & + & + & na & - & + & {$[41,76]$} \\
\hline $\mathrm{CP}-6$ & USA & $\mathrm{NE}$ & + & + & na & na & na & {$[77,78]$} \\
\hline EHE-NE18 & Australia & NE & + & + & + & - & + & {$[37,39,75,79,80]$} \\
\hline WER-NE36 & Australia & NE & + & + & - & - & + & {$[37,75,79,80]$} \\
\hline CP1 & Canada & NE & + & + & na & na & + & {$[52,81]$} \\
\hline Strain 56 & Belgium & NE & + & + & + & na & - & {$[82,83]$} \\
\hline S48 & Denmark & $\mathrm{NE}$ & + & + & na & na & na & {$[60,84]$} \\
\hline
\end{tabular}

${ }^{\mathrm{A}} \mathrm{NE}=$ necrotic enteritis. ${ }^{\mathrm{B}}$ na $=$ not available. 


\section{Incidence of NetB-Positive $C$. perfringens Isolated from Broilers}

Since the discovery of the NetB toxin as an essential virulence factor in NE, the prevalence of netB-positive $C$. perfringens isolates in NE disease outbreaks has been reported (Table 4). In general, culture methods utilizing media and agar were used to isolate C. perfringens from chicken digesta or litter samples prior to the net $B$ genotyping with polymerase chain reaction (PCR) or quantitative PCR. C. perfringens can be directly isolated by plating gut or environmental samples on selective agar (e.g., TSC agar) or by a liquid culture (e.g., FTG, CMM, or BHI) followed by plating on solid agar (e.g., TSC, blood, or $\mathrm{BHI})$. The function of selective media for $\mathrm{C}$. perfringens has been documented elsewhere [71] although their contributions to growth and toxin production have not studied.

Table 4. Incidence of necrotic enteritis (NE) B-like toxin gene in Clostridium perfringens G isolates from retail chicken meats or chickens afflicted with or without clinical or subclinical NE.

\begin{tabular}{|c|c|c|c|c|c|c|c|}
\hline \multirow{2}{*}{ Country } & \multirow{2}{*}{ Study Year ${ }^{A}$} & \multirow{2}{*}{$\begin{array}{l}\text { Detection } \\
\text { Method }\end{array}$} & \multicolumn{2}{|c|}{ NE Chicken, $n /$ Total } & \multicolumn{2}{|c|}{ Healthy Chicken, $n /$ Total } & \multirow{2}{*}{ Ref. } \\
\hline & & & NetB Positive & $\%$ & NetB Positive & $\%$ & \\
\hline Australia & 2010 & PCR & $14 / 18$ & 77.8 & - & - & [25] \\
\hline $\begin{array}{l}\text { Australia/Canada/ } \\
\text { Belgium/Denmark }\end{array}$ & 2010 & PCR & $31 / 44$ & 70.5 & $2 / 55$ & 3.6 & [85] \\
\hline Brazil & 2012 & PCR & $0 / 22$ & 0.0 & - & - & [86] \\
\hline Canada & 2005-2007 & PCR & $39 / 41$ & 95.1 & $7 / 20$ & 35.0 & [87] \\
\hline Canada & 2011-2012 & PCR & $9 / 45$ & 20.0 & $12 / 18$ & 66.7 & [62] \\
\hline Canada & 2011-2012 & PCR & $41 / 41$ & 100.0 & $26 / 30$ & 86.7 & [62] \\
\hline Canada & 2010 & PCR & $6 / 6$ & 100.0 & $4 / 5$ & 80.0 & [66] \\
\hline Canada ${ }^{B}$ & 2010 & PCR & - & - & $39 / 183$ & 21.3 & [88] \\
\hline Denmark & 1997-2002 & PCR & $13 / 25$ & 52.0 & $14 / 23$ & 60.9 & [60] \\
\hline $\begin{array}{l}\text { Denmark/ } \\
\text { Finland }\end{array}$ & 1997-2001 & PCR & $12 / 22$ & 54.5 & $0 / 8$ & 0.0 & [89] \\
\hline Iran & 2016 & PCR & $8 / 45$ & 17.8 & - & - & [90] \\
\hline Italy ${ }^{C}$ & 2015-2017 & qPCR & - & - & $31 / 151$ & 20.5 & [65] \\
\hline Italy & 2009 & PCR & $16 / 30$ & 53.3 & $4 / 22$ & 18.2 & [91] \\
\hline Korea & 2010-2012 & PCR & $8 / 17$ & 47.1 & $2 / 50$ & 4.0 & [61] \\
\hline Korea ${ }^{\mathrm{B}}$ & 2018 & PCR & - & - & $4 / 9$ & 44.4 & [92] \\
\hline Netherlands & 2012 & PCR & $43 / 45$ & 95.6 & - & - & [26] \\
\hline Sweden & 2004 & PCR & $31 / 34$ & 91.2 & $-\mathrm{D}$ & 25.0 & [93] \\
\hline Sweden & 2004 & PCR & $16 / 23$ & 69.6 & - & - & [93] \\
\hline Sweden & 2004 & PCR & $0 / 11$ & 0.0 & - & - & [93] \\
\hline USA & 2004-2009 & PCR & $17 / 20$ & 85.0 & $10 / 54$ & 18.5 & [67] \\
\hline USA & 2009 & PCR & $7 / 12$ & 58.3 & $7 / 80$ & 8.8 & [59] \\
\hline USA & 2018 & qPCR & $11 / 15$ & 73.3 & $9 / 15$ & 60.0 & [63] \\
\hline USA & 2016 & PCR & $119 / 145$ & 82.1 & $59 / 85$ & 69.4 & [64] \\
\hline USA & $2003-2004$ & PCR & $19 / 19$ & 100.0 & - & - & [47] \\
\hline
\end{tabular}

${ }^{A}=$ year of publication was provided unless the studied year was not indicated. ${ }^{B}=$ retail chicken meats. ${ }^{C}=$ flock surveillance with no health status. ${ }^{\mathrm{D}}=$ not specified.

Several conclusions can be drawn from studies that describe C. perfringens isolation from NE-afflicted or healthy chickens (Table 4): (1) Field NE occurs globally, (2) netBpositive $C$. perfringens are isolated from both NE-afflicted and healthy chickens, (3) netBpositive $C$. perfringens is more abundant in NE-afflicted vs. healthy chickens, (4) netBpositive C. perfringens may not be isolated from confirmed NE clinical cases, (5) netBnegative $C$. perfringens can be isolated from NE-afflicted chickens, and (6) netB-positive C. perfringens can be detected in retail broiler meats. Thus, these findings indicate that 
$\mathrm{NE}$ is a complex disease caused by multiple contributing and predisposing factors (e.g., C. perfringens toxins, Eimeria, stress, nutrition, or environment) although the NetB toxin is considered to be the primary virulent factor.

\section{In Vitro and In Vivo NetB Production by NetB-Positive $C$. perfringens Isolates}

Until recently, native NetB protein was only detected in vitro in culture supernatants from netB-positive $C$. perfringens strains by Western blot analysis using polyclonal antirecombinant NetB antiserum [39,53,60,85] or a cell-based cytotoxicity assay [39,94]. Abildgaard et al. showed that 12 out of 13 C. perfringens isolates from NE chickens were NetB positive whereas only 4 out of $14 C$. perfringens strains from healthy chickens produced NetB [60]. This study also emphasized that C. perfringens isolated from NE-afflicted chickens secreted much higher amounts of NetB toxin in vitro compared to those from normal chickens. Allaart et al. reported that 9 out of 43 netB-positive $C$. perfringens strains isolated from hens with subclinical NE produced NetB protein in vitro [26]. There are no reports showing in vitro NetB production by netB-negative $C$. perfringens. In one study, all 22 netB-positive $C$. perfringens strains isolated from chickens with clinical NE produced NetB [85]. These studies collectively indicate that not all netB-positive $C$. perfringens may secrete NetB in vitro. The conflicting results may be related to the difference in net $B$ gene copy number among netB-positive $C$. perfringens isolates. Indeed, $\mathrm{Gu}$ et al. isolated 18 netB-positive $C$. perfringens from NE-afflicted chickens and showed that only half of the netB-positive $C$. perfringens strains had higher netB gene copy numbers relative to their $16 \mathrm{~S}$ rDNA levels [47]. Gu's observation [47] suggests that the presence of the net $B$ gene in C. perfringens does not guarantee the secretion of the NetB toxin in vitro.

A detection method to measure native NetB protein in biological samples (e.g., from NE-afflicted or healthy chickens) is not currently available. With increasing restriction of antibiotic-free poultry production, there is a need to develop a high throughput, reliable analytical tool to detect native NetB protein in biological samples to adequately address several questions related to fundamental and applied research on NE: (1) whether in vitro and in vivo production of NetB protein by netB-positive $C$. perfringens is related, (2) whether in vivo NetB protein can be detected by netB-negative $C$. perfringens in NE models, and (3) whether routine screening of biological samples (feces, litters, tissues, or sera) can predict virulent $C$. perfringens NE outbreaks on farms for timely management. The recent development of a NetB antigen-specific ELISA system [95] to detect and quantify NetB in biological samples should enhance our ability to manage field NE outbreaks. Lee et al. developed multiple NetB-specific monoclonal antibody pairs for capture ELISA to detect Escherichia coli NetB protein and native NetB protein secreted by netB-positive $C$. perfringens isolates [95]. Furthermore, the availability of a NetB-specific ELISA will make it possible to quantify the NetB toxin in vitro and in vivo. For example, Keyburn et al. showed that 1:16-diluted culture supernatant of netB-positive $C$. perfringens exhibited cytopathic effects in LMH cells in vitro [39]. In addition, Keyburn et al. found that purified NetB protein ranging from 1.89 to $242.4 \mathrm{nM}$ (calculated from $8 \mu \mathrm{g}$ to $62.5 \mathrm{ng} /$ well in 24-well format) was cytotoxic to LMH cells [39]. Similarly, Savva et al. observed that purified NetB induced morphological damage in LMH cells [38]. However, Savva et al. used much higher NetB concentrations ranging from 62.5 to $4000 \mathrm{nM}$ (calculated from $412.5 \mathrm{ng}$ to $26.4 \mu \mathrm{g} /$ well in 96-well format) in a cytotoxicity assay with a median cytotoxic dose of $800 \mathrm{nM}$ [38]. Until recently, it is not known whether those cytotoxic concentrations are biologically relevant to $\mathrm{NE}$ development in vivo. Lee et al. for the first time detected and reported the approximate concentration of NetB toxin to be $2.23 \mathrm{nM}$ in the gut digesta from NE-afflicted broiler chickens [96]. The latter study [96] concluded that low NetB toxin concentrations used in vitro studies [39] are likely to be biologically relevant to induce NE development in vivo.

\section{Concluding Remarks}

$\mathrm{NE}$ is not only an emerging threat to the global broiler industry but also compromises the welfare and health of commercial poultry in the era of antibiotic-independent poultry 
production [12,97]. This threat will be enhanced under the "No Antibiotics Ever (NAE)" and "Antibiotic-free" (ABF) broiler production systems. Thus, understanding NE pathogenesis and developing sensitive detection assay are important to reduce economic losses due to $\mathrm{NE}$ and to develop early management strategies against NE. With the development of molecular and proteomic technologies, the NetB toxin has been regarded as the primary virulence factor in NE pathogenesis. However, new scientific evidence is emerging to implicate other $C$. perfringens toxins and enzymes that can potentiate NE pathogenesis with or without NetB. Although the presence of netB in C. perfringens isolates can be typed with PCR and the NetB protein can be detected using Western blots, there is a need for a more defined large-scale immunoassay that can detect toxins associated with NE pathogenesis in the field samples from NE-afflicted farms. Recent availability of NetBspecific mouse monoclonal antibodies and a high throughput ELISA detection system will now allow sensitive NetB detection in samples from poultry farms. These NetBspecific monoclonal antibody-based detection assays will be a valuable tool in addressing fundamental questions of host-pathogen immunobiology in NE and as a screening tool for validating the efficacy of novel alternative-to-antibiotics feed additives or vaccines to mitigate the negative effects of NE.

Author Contributions: Conceptualization, K.-W.L. and H.S.L.; writing—original draft preparation, K.-W.L.; writing-review and editing, K.-W.L. and H.S.L. All authors have read and agreed to the published version of the manuscript.

Funding: This research was supported by USDA/NIFA SAS award 2020-69012-31823; accession number 12023193.

Institutional Review Board Statement: Not applicable.

Informed Consent Statement: Not applicable.

Data Availability Statement: Not applicable.

Conflicts of Interest: No potential conflict of interest were reported by the authors.

\section{References}

1. Godfray, H.C.J.; Beddington, J.R.; Crute, I.R.; Haddad, L.; Lawrence, D.; Muir, J.F.; Pretty, J.; Robinson, S.; Thomas, S.M.; Toulmin, C. Food security: The challenge of feeding 9 billion people. Science 2010, 327, 812-818. [CrossRef] [PubMed]

2. Lee, K.-W.; Lillehoj, H.S. An update on direct-fed microbials in broiler chickens in post-antibiotic era. Anim. Prod. Sci. 2017, 57, 1575. [CrossRef]

3. St-Pierre, N.; Cobanov, B.; Schnitkey, G. Economic losses from heat stress by US livestock industries. J. Dairy Sci. 2003, 86, E52-E77. [CrossRef]

4. Blake, D.P.; Knox, J.; Dehaeck, B.; Huntington, B.; Rathinam, T.; Ravipati, V.; Ayoade, S.; Gilbert, W.; Adebambo, A.O.; Jatau, I.D.; et al. Re-calculating the cost of coccidiosis in chickens. Vet. Res. 2020, 51, 115. [CrossRef]

5. Gadde, U.; Kim, W.H.; Oh, S.T.; Lillehoj, H.S. Alternatives to antibiotics for maximizing growth performance and feed efficiency in poultry: A review. Anim. Heal. Res. Rev. 2017, 18, 26-45. [CrossRef]

6. An, B.-K.; Choi, Y.-I.; Kang, C.-W.; Lee, K.-W. Effects of dietary Corynebacterium ammoniagenes-derived single cell protein on growth performance, blood and tibia bone characteristics, and meat quality of broiler chickens. J. Anim. Feed. Sci. 2018, 27, 140-147. [CrossRef]

7. Grant, A.; Gay, C.; Lillehoj, H.S. Bacillus spp. as direct-fed microbial antibiotic alternatives to enhance growth, immunity, and gut health in poultry. Avian Pathol. 2018, 47, 339-351. [CrossRef] [PubMed]

8. Kim, D.H.; Han, S.M.; Keum, M.C.; Lee, S.; An, B.K.; Lee, K.-W. Evaluation of bee venom as a novel feed additive in fast-growing broilers. Br. Poult. Sci. 2018, 59, 435-442. [CrossRef] [PubMed]

9. Ndazigaruye, G.; Kim, D.-H.; Kang, C.-W.; Kang, K.-R.; Joo, Y.-J.; Lee, S.-R.; Lee, K.-W. Effects of low-protein diets and exogenous protease on growth performance, carcass traits, intestinal morphology, cecal volatile fatty acids and serum parameters in broilers. Animals 2019, 9, 226. [CrossRef] [PubMed]

10. Oh, S.; Lillehoj, H.S.; Lee, Y.; Bravo, D.; Lillehoj, E.P. Dietary antibiotic growth promoters down-regulate intestinal inflammatory cytokine expression in chickens challenged with LPS or co-infected with Eimeria maxima and Clostridium perfringens. Front. Vet. Sci. 2019, 6, 420. [CrossRef]

11. Hofacre, C.L.; Smith, J.A.; Mathis, G.F. An optimist's view on limiting necrotic enteritis and maintaining broiler gut health and performance in today's marketing, food safety, and regulatory climate. Poult. Sci. 2018, 97, 1929-1933. [CrossRef] 
12. Van Immerseel, F.; De Buck, J.; Pasmans, F.; Huyghebaert, G.; Haesebrouck, F.; Ducatelle, R. Clostridium perfringens in poultry: An emerging threat for animal and public health. Avian Pathol. 2004, 33, 537-549. [CrossRef]

13. Tsiouris, V. Poultry management: A useful tool for the control of necrotic enteritis in poultry. Avian Pathol. 2016, 45, 323-325. [CrossRef]

14. Broom, L. Necrotic enteritis; current knowledge and diet-related mitigation. World's Poult. Sci. J. 2017, 73, 281-292. [CrossRef]

15. Cooper, K.; Songer, J.G.; Uzal, F.A. Diagnosing clostridial enteric disease in poultry. J. Vet. Diagn. Investig. 2013, 25, 314-327. [CrossRef] [PubMed]

16. Caly, D.L.; D'lnca, R.; Auclair, E.; Drider, D. Alternatives to antibiotics to prevent necrotic enteritis in broiler chickens: A microbiologist's perspective. Front. Microbiol. 2015, 6, 1336. [CrossRef]

17. Kaldhusdal, M.; Løvland, A. The economical impact of Clostridium perfringens is greater than anticipated. World Poult. 2000, 16, 50-51.

18. Løvland, A.; Kaldhusdal, K. Liver lesions seen at slaughter as an indicator of necrotic enteritis in broiler flocks. FEMS Microbiol. Immunol. 1999, 24, 345-351. [CrossRef]

19. Wade, B.; Keyburn, A. The true cost of necrotic enteritis. World Poult. 2015, 31, 16-17.

20. Li, J.; Adams, V.; Bannam, T.L.; Miyamoto, K.; Garcia, J.P.; Uzal, F.A.; Rood, J.I.; McClane, B.A. Toxin plasmids of Clostridium perfringens. MMBR 2013, 77, 208-233. [CrossRef]

21. Rood, J.I.; Adams, V.; Lacey, J.; Lyras, D.; McClane, B.A.; Melville, S.B.; Moore, R.J.; Popoff, M.R.; Sarker, M.R.; Songer, J.G.; et al. Expansion of the Clostridium perfringens toxin-based typing scheme. Anaerobe 2018, 53, 5-10. [CrossRef] [PubMed]

22. Kiu, R.; Hall, L.J. An update on the human and animal enteric pathogen Clostridium perfringens. Emerg. Microbes Infect. 2018, 7 , 1-15. [CrossRef]

23. Ohtani, K.; Shimizu, T. Regulation of toxin production in Clostridium perfringens. Toxins 2016, 8, 207. [CrossRef]

24. Mi, E.; Li, J.; McClane, B.A. NanR Regulates Sporulation and Enterotoxin Production by Clostridium perfringens Type F Strain F4969. Infect. Immun. 2018, 86, e00416-18. [CrossRef]

25. Keyburn, A.L.; Bannam, T.L.; Moore, R.J.; Rood, J.I. NetB, a pore-forming toxin from necrotic enteritis strains of Clostridium perfringens. Toxins 2010, 2, 1913-1927. [CrossRef]

26. Allaart, J.G.; de Bruijn, N.D.; van Asten, A.J.A.M.; Fabri, T.H.F.; Gröne, A. NetB-producing and beta2-producing Clostridium perfringens associated with subclincal necrotic enteritis in laying hens in the Netherlands. Avian Pathol. 2012, 41, 541-546. [CrossRef]

27. Revitt-Mills, S.A.; Rood, J.I.; Adams, V. Clostridium perfringens extracellular toxins and enzymes: 20 and counting. Microbiol. Aust. 2015, 36, 114. [CrossRef]

28. Oda, M.; Terao, Y.; Sakurai, J.; Nagahama, M. Membrane-Binding Mechanism of Clostridium perfringens Alpha-Toxin. Toxins 2015, 7, 5268-5275. [CrossRef]

29. Navarro, M.A.; McClane, B.A.; Uzal, F.A. Mechanisms of Action and Cell Death Associated with Clostridium perfringens Toxins. Toxins 2018, 10, 212. [CrossRef] [PubMed]

30. Popoff, M.R. Clostridium pore-forming toxins: Powerful virulence factors. Anaerobe 2014, 30, 220-238. [CrossRef] [PubMed]

31. Matsushita, O.; Yoshihara, K.; Katayama, S.; Minami, J.; Okabe, A. Purification and characterization of Clostridium perfringens 120-kilodalton collagenase and nucleotide sequence of the corresponding gene. J. Bacteriol. 1994, 176, 149-156. [CrossRef]

32. Wang, Y.-H. Sialidases from Clostridium perfringens and their inhibitors. Front. Cell. Infect. Microbiol. 2020, 9, 462. [CrossRef]

33. Li, C.; Yan, X.; Lillehoj, H.S. Complete genome sequences of Clostridium perfringens Del1 strain isolated from chickens affected by necrotic enteritis. Gut Pathog 2017, 9, 69. [CrossRef]

34. Newstead, S.; Potter, J.A.; Wilson, J.C.; Xu, G.; Chien, C.-H.; Watts, A.; Withers, S.G.; Taylor, G. The structure of Clostridium perfringens nani sialidase and its catalytic intermediates. J. Biol. Chem. 2008, 283, 9080-9088. [CrossRef]

35. Shimizu, T.; Ohtani, K.; Hirakawa, H.; Ohshima, K.; Yamashita, A.; Shihba, T.; Ogasawara, N.; Hattori, M.; Kuhara, S.; Hayashi, H. Complete genome sequence of Clostridium perfringens, an anaerobic flesh-eater. Proc. Natl. Acad. Sci. USA 2002, 99, $996-1001$. [CrossRef]

36. Goossens, E.; Valgaeren, B.R.; Pardon, B.; Haesebrouck, F.; Ducatelle, R.; Deprez, P.R.; Van Immerseel, F. Rethinking the role of alpha toxin in Clostridium perfringens-associated enteric diseases: A review on bovine necro-haemorrhagic enteritis. Vet. Res. 2017, 48, 9. [CrossRef] [PubMed]

37. Wade, B.; Keyburn, A.; Seemann, T.; Rood, J.; Moore, R. Binding of Clostridium perfringens to collagen correlates with the ability to cause necrotic enteritis in chickens. Vet. Microbiol. 2015, 180, 299-303. [CrossRef] [PubMed]

38. Savva, C.G.; da Costa, S.P.F.; Bokori-Brown, M.; Naylor, C.E.; Cole, A.R.; Moss, D.S.; Titball, R.W.; Basak, A.K. Molecular architecture and functional analysis of NetB, a pore-forming toxin from Clostridium perfringens. J. Biol. Chem. 2013, 288, 3512-3522. [CrossRef] [PubMed]

39. Keyburn, A.L.; Boyce, J.D.; Vaz, P.; Bannam, T.L.; Ford, M.E.; Parker, D.; Di Rubbo, A.; Rood, J.I.; Moore, R.J. NetB, a new toxin that is associated with avian necrotic enteritis caused by Clostridium perfringens. PLOS Pathog. 2008, 4, e26. [CrossRef] [PubMed]

40. Schotte, U.; Truyen, U.; Neubauer, H. Significance of $\beta 2$-toxigenic Clostridium perfringens infections in animals and their predisposing factors-A review. J. Vet. Med. B 2004, 51, 423-426. [CrossRef]

41. Chen, J.; McClane, B.A. Characterization of Clostridium perfringens TpeL Toxin Gene Carriage, Production, Cytotoxic Contributions, and Trypsin Sensitivity. Infect. Immun. 2015, 83, 2369-2381. [CrossRef] [PubMed] 
42. Coursodon, C.F.; Glock, R.D.; Moore, K.L.; Cooper, K.K.; Songer, J.G. TpeL-producing strains of Clostridium perfringens type A are highly virulent for broiler chicks. Anaerobe 2012, 18, 117-121. [CrossRef]

43. Guttenberg, G.; Hornei, S.; Jank, T.; Schwan, C.; Lü, W.; Einsle, O.; Papatheodorou, P.; Aktories, K. Molecular char-acteristics of Clostridium perfringens TpeL toxin and consequences of mono-O-GlcNAcylation of Ras in living cells. J. Biol. Chem. 2012, 287, 24929-24940. [CrossRef]

44. Crespo, R.; Fisher, D.J.; Shivaprasad, H.L.; Fernández-Miyakawa, M.E.; Uzal, F.A. Toxinotypes of Clostridium perfringens isolated from sick and healthy Avian Species. J. Vet. Diagn. Investig. 2007, 19, 329-333. [CrossRef]

45. França, M.; Barrios, M.A.; Stabler, L.; Zavala, G.; Shivaprasad, H.L.; Lee, M.D.; Villegas, A.M.; Uzal, F.A. Association of Beta2PositiveClostridium perfringensType A With Focal Duodenal Necrosis in Egg-Laying Chickens in the United States. Avian Dis. 2016, 60, 43-49. [CrossRef] [PubMed]

46. Bueschel, D.M.; Jost, B.H.; Billington, S.J.; Trinh, H.T.; Songer, J.G. Prevalence of cpb2, encoding beta2 toxin, in Clostridium perfringens field isolates: Correlation of genotype with phenotype. Vet. Microbiol. 2003, 94, 121-129. [CrossRef]

47. Gu, C.; Lillehoj, H.S.; Sun, Z.; Lee, Y.; Zhao, H.; Xianyu, Z.; Yan, X.; Wang, Y.; Lin, S.; Liu, L.; et al. Characterization of virulent netB+/tpeL+Clostridium perfringens strains from necrotic enteritis-afflicted broiler chicken farms. Avian Dis. 2019, 63, 461-467. [CrossRef] [PubMed]

48. Matsushita, O.; Okabe, A. Clostridial hydrolytic enzymes degrading extracellular components. Toxicon 2001, 39, 1769-1780 [CrossRef]

49. Li, J.; Sayeed, S.; Robertson, S.; Chen, J.; McClane, B.A. Sialidases affect the host cell adherence and epsilon tox-in-induced cytotoxicity of Clostridium perfringens type D strain CN3718. PLoS Pathog. 2011, 7, e1002429. [CrossRef] [PubMed]

50. Olkowski, A.; Wojnarowicz, C.; Chirino-Trejo, M.; Laarveld, B.; Sawicki, G. Sub-clinical necrotic enteritis in broiler chickens: Novel etiological consideration based on ultra-structural and molecular changes in the intestinal tissue. Res. Vet. Sci. 2008, 85, 543-553. [CrossRef]

51. Wade, B.; Keyburn, A.L.; Haring, V.; Ford, M.; Rood, J.I.; Moore, R.J. The adherent abilities of Clostridium perfringens strains are critical for the pathogenesis of avian necrotic enteritis. Vet. Microbiol. 2016, 197, 53-61. [CrossRef] [PubMed]

52. Parreira, V.R.; Costa, M.; Eikmeyer, F.; Blom, J.; Prescott, J.F. Sequence of two plasmids from clostridium perfringens chicken necrotic enteritis isolates and comparison with c. perfringens conjugative plasmids. PLoS ONE 2012, 7, e49753. [CrossRef] [PubMed]

53. Yan, X.-X.; Porter, C.J.; Hardy, S.P.; Steer, D.; Smith, I.; Quinsey, N.S.; Hughes, V.; Cheung, J.K.; Keyburn, A.L.; Kaldhusdal, M.; et al. Structural and functional analysis of the pore-forming toxin NetB from Clostridium perfringens. mBio 2013, 4, e00019-13. [CrossRef]

54. Yu, Q.; Lepp, D.; Gohari, I.M.; Wu, T.; Zhou, H.; Yin, X.; Yu, H.; Prescott, J.F.; Nie, S.-P.; Xie, M.-Y.; et al. The agr-like quorum sensing system is required for pathogenesis of necrotic enteritis caused by Clostridium perfringens in poultry. Infect. Immun. 2017, 85, e00975-e16. [CrossRef]

55. Lepp, D.; Roxas, B.; Parreira, V.R.; Marri, P.R.; Rosey, E.L.; Gong, J.; Songer, J.G.; Vedantam, G.; Prescott, J.F. Identification of novel pathogenicity loci in Clostridium perfringens strains that cause avian necrotic enteritis. PLoS ONE 2010, 5, e10795. [CrossRef]

56. Keyburn, A.L.; Sheedy, S.A.; Ford, M.E.; Williamson, M.M.; Awad, M.M.; Rood, J.I.; Moore, R.J. Alpha-Toxin of Clostridium perfringens is not an essential virulence factor in necrotic enteritis in chickens. Infect. Immun. 2006, 74, 6496-6500. [CrossRef]

57. Coursodon, C.F.; Trinh, H.T.; Mallozzi, M.; Vedantam, G.; Glock, R.; Songer, J. Clostridium perfringens alpha toxin is produced in the intestines of broiler chicks inoculated with an alpha toxin mutant. Anaerobe 2010, 16, 614-617. [CrossRef] [PubMed]

58. Zhou, H.; Lepp, D.; Pei, Y.; Liu, M.; Yin, X.; Ma, R.; Prescott, J.F.; Gong, J. Influence of pCP1NetB ancillary genes on the virulence of Clostridium perfringens poultry necrotic enteritis strain CP1. Gut Pathog. 2017, 9, 6. [CrossRef]

59. Martin, T.G.; Smyth, J.A. Prevalence of netB among some clinical isolates of Clostridium perfringens from animals in the United States. Vet. Microbiol. 2009, 136, 202-205. [CrossRef] [PubMed]

60. Abildgaard, L.; Søndergaard, T.; Engberg, R.M.; Schramm, A.; Højberg, O. In vitro production of necrotic enteritis toxin B, NetB, by netB-positive and netB-negative Clostridium perfringens originating from healthy and diseased broiler chickens. Vet. Microbiol. 2010, 144, 231-235. [CrossRef]

61. Park, J.Y.; Kim, S.; Oh, J.Y.; Kim, H.R.; Jang, I.; Lee, H.S.; Kwon, Y.K. Characterization of Clostridium perfringens isolates obtained from 2010 to 2012 from chickens with necrotic enteritis in Korea. Poult. Sci. 2015, 94, 1158-1164. [CrossRef]

62. Gaucher, M.-L.; Perron, G.G.; Arsenault, J.; Letellier, A.; Boulianne, M.; Quessy, S. Recurring necrotic enteritis outbreaks in commercial broiler chicken flocks strongly influence toxin gene carriage and species richness in the resident Clostridium perfringens population. Front. Microbiol. 2017, 8, 881. [CrossRef]

63. Yang, W.Y.; Chou, C.H.; Wang, C. Characterization of toxin genes and quantitative analysis of netB in necrotic en-teritis (NE)-producing and non-NE-producing Clostridium perfringens isolated from chickens. Anaerobe 2018, 54, 115-120. [CrossRef] [PubMed]

64. Mwangi, S.; Timmons, J.; Fitz-Coy, S.; Parveen, S. Characterization of Clostridium perfringens recovered from broiler chicken affected by necrotic enteritis. Poult. Sci. 2019, 98, 128-135. [CrossRef] [PubMed]

65. Profeta, F.; Di Francesco, C.E.; Di Provvido, A.; Scacchia, M.; Alessiani, A.; Di Giannatale, E.; Marruchella, G.; Orsini, M.; Toscani, T.; Marsilio, F. Prevalence of netB-positive Clostridium perfringens in Italian poultry flocks by environmental sampling. J. Vet. Diagn. 2020, 32, 252-258. [CrossRef] [PubMed] 
66. Brady, J.; Hernandez-Doria, J.D.; Bennett, C.; Guenter, W.; House, J.D.; Rodriguez-Lecompte, J.C. Toxinotyping of necrotic enteritis-producing and commercial isolates of Clostridium perfringens from chickens fed organic diets. Avian Pathol. 2010, 39, 475-481. [CrossRef]

67. Hibberd, M.C.; Neumann, A.P.; Rehberger, T.G.; Siragusa, G.R. Multilocus sequence typing subtypes of poultry Clostridium perfringens isolates demonstrate disease niche partitioning. J. Clin. Microbiol. 2011, 49, 1556-1567. [CrossRef]

68. Li, C.; Lillehoj, H.S.; Gadde, U.D.; Ritter, D.; Oh, S. Characterization of Clostridium perfringens strains isolated from healthy and necrotic enteritis-afflicted broiler chickens. Avian Dis. 2017, 61, 178-185. [CrossRef]

69. Cooper, K.K.; Songer, J.G. Virulence of Clostridium perfringens in an experimental model of poultry necrotic enteritis. Vet. Microbiol. 2010, 142, 323-328. [CrossRef]

70. Timbermont, L.; Haesebrouck, F.; Ducatelle, R.; Van Immerseel, F. Necrotic enteritis in broilers: An updated review on the pathogenesis. Avian Pathol. 2011, 40, 341-347. [CrossRef]

71. Prescott, J.F.; Parreira, V.R.; Gohari, I.M.; Lepp, D.; Gong, J. The pathogenesis of necrotic enteritis in chickens: What we know and what we need to know: A review. Avian Pathol. 2016, 45, 288-294. [CrossRef]

72. Rood, J.I.; Keyburn, A.L.; Moore, R.J. NetB and necrotic enteritis: The hole movable story. Avian Pathol. 2016, 45, $295-301$. [CrossRef]

73. Barbara, A.J.; Trinh, H.T.; Glock, R.D.; Songer, J.G. Necrotic enteritis-producing strains of Clostridium perfringens displace non-necrotic enteritis strains from the gut of chicks. Vet. Microbiol. 2008, 126, 377-382. [CrossRef] [PubMed]

74. Moran, E.T. Intestinal events and nutritional dynamics predispose Clostridium perfringens virulence in broilers. Poult. Sci. 2014, 93, 3028-3036. [CrossRef] [PubMed]

75. Kiu, R.; Brown, J.; Bedwell, H.; Leclaire, C.; Caim, S.; Pickard, D.; Dougan, G.; Dixon, R.A.; Hall, L.J. Genomic analysis on broiler-associated Clostridium perfringens strains and exploratory caecal microbiome investigation reveals key factors linked to poultry necrotic enteritis. Anim. Microbiome 2019, 1, 12. [CrossRef]

76. Cooper, K.K.; Theoret, J.R.; Stewart, B.A.; Trinh, H.T.; Glock, R.D.; Songer, J.G. Virulence for chickens of Clostridium perfringens isolated from poultry and other sources. Anaerobe 2010, 16, 289-292. [CrossRef]

77. Miller, R.W.; Skinner, E.J.; Sulakvelidze, A.; Mathis, G.F.; Hofacre, C.L. Bacteriophage Therapy for Control of Necrotic Enteritis of Broiler Chickens Experimentally Infected with Clostridium perfringens. Avian Dis. 2010, 54, 33-40. [CrossRef] [PubMed]

78. Richardson, K.; Hofacre, C.; Mathis, G.; Lumpkins, B.; Phillips, R. Impact of Controlling Bacteria in Feed on Broiler Performance During a Clostridial Challenge. Avian Dis. 2017, 61, 453-456. [CrossRef] [PubMed]

79. Naseri, K.G.; Kheravii, S.; Keerqin, C.; Morgan, N.; Swick, R.; Choct, M.; Wu, S.-B. Two different Clostridium perfringens strains produce different levels of necrotic enteritis in broiler chickens. Poult. Sci. 2019, 98, 6422-6432. [CrossRef] [PubMed]

80. Lacey, J.A.; Allnutt, T.R.; Vezina, B.; Van, T.T.H.; Stent, T.; Han, X.; Rood, J.I.; Wade, B.; Keyburn, A.L.; Seemann, T.; et al. Whole genome analysis reveals the diversity and evolutionary relationships between necrotic enteritis-causing strains of Clostridium perfringens. BMC Genom. 2018, 19, 379. [CrossRef]

81. Yang, W.Y.; Lee, Y.J.; Lu, H.Y.; Branton, S.L.; Chou, C.H.; Wang, C. The netB-positive Clostridium perfringens in the experimental induction of necrotic enteritis with or without predisposing factors. Poult. Sci. 2019, 98, 5297-5306. [CrossRef]

82. Gholamiandekhordi, A.R.; Ducatelle, R.; Heyndrickx, M.; Haesebrouck, F.; Van Immerseel, F. Molecular and phe-notypical characterization of Clostridium perfringens isolates from poultry flocks with different disease status. Vet. Microbiol. 2006, 113, 143-152. [CrossRef]

83. Eeckhaut, V.; Wang, J.; Van Parys, A.; Haesebrouck, F.; Joossens, M.; Falony, G.; Raes, J.; Ducatelle, R.; Van Immerseel, F. The probiotic butyricicoccus pullicaecorum reduces feed conversion and protects from potentially harmful intestinal microorganisms and necrotic enteritis in broilers. Front. Microbiol. 2016, 7, 1416. [CrossRef] [PubMed]

84. Sharma, N.; Ranjitkar, S.; Sharma, N.K.; Engberg, R.M. Influence of feeding crimped kernel maize silage on the course of subclinical necrotic enteritis in a broiler disease model. Anim. Nutr. 2017, 3, 392-398. [CrossRef] [PubMed]

85. Keyburn, A.L.; Yan, X.X.; Bannam, T.L.; Van Immerseel, F.; Rood, J.I.; Moore, R.J. Association between avian necrotic enteritis and Clostridium perfringens strains expressing NetB toxin. Vet. Res. 2010, 41, 21. [CrossRef] [PubMed]

86. Llanco, L.A.; Viviane, N.; Ferreira, A.J.P.; Avila-Campos, M.J. Toxinotyping and antimicrobial susceptibility of Clostridium perfringens isolated from broiler chickens with necrotic enteritis. Int. J. Microbiol. Res. 2012, 4, 290-294.

87. Chalmers, G.; Bruce, H.L.; Hunter, D.B.; Parreira, V.R.; Kulkarni, R.R.; Jiang, Y.-F.; Prescott, J.F.; Boerlin, P. Multilocus sequence typing analysis of Clostridium perfringens isolates from necrotic enteritis outbreaks in broiler chicken populations. J. Clin. Microbiol. 2008, 46, 3957-3964. [CrossRef]

88. Nowell, V.J.; Poppe, C.; Parreira, V.R.; Jiang, Y.-F.; Reid-Smith, R.; Prescott, J.F. Clostridium perfringens in retail chicken. Anaerobe 2010, 16, 314-315. [CrossRef]

89. Ronco, T.; Stegger, M.; Ng, K.L.; Lilje, B.; Lyhs, U.; Andersen, P.S.; Pedersen, K. Genome analysis of Clostridium perfringens isolates from healthy and necrotic enteritis infected chickens and turkeys. BMC Res. Notes 2017, 10, 270. [CrossRef]

90. Ezatkhah, M.; Alimolaei, M.; Shahdadnejad, N. The Prevalence of netB Gene in Isolated Clostridium perfringens From Organic Broiler Farms Suspected to Necrotic Enteritis. Int. J. Enteric Pathog. 2016, 4, 3-35667. [CrossRef]

91. Drigo, I.; Agnoletti, F.; Bacchin, C.; Guolo, A.; Cocchi, M.; Bonci, M.; Bano, L. Diffusion of Clostridium perfringens NetB positive strains in healthy and diseased chickens. Ital. J. Anim. Sci. 2009, 8, 761-764. [CrossRef] 
92. Hu, W.-S.; Kim, H.; Koo, O.K. Molecular genotyping, biofilm formation and antibiotic resistance of enterotoxigenic Clostridium perfringens isolated from meat supplied to school cafeterias in South Korea. Anaerobe 2018, 52, 115-121. [CrossRef] [PubMed]

93. Johansson, A.; Aspán, A.; Kaldhusdal, M.; Engström, B.E. Genetic diversity and prevalence of netB in Clostridium perfringens isolated from a broiler flock affected by mild necrotic enteritis. Vet. Microbiol. 2010, 144, 87-92. [CrossRef] [PubMed]

94. Smyth, J.A.; Martin, T.G. Disease producing capability of netB positive isolates of $C$. perfringens recovered from normal chickens and a cow, and netB positive and negative isolates from chickens with necrotic enteritis. Vet. Microbiol. 2010, 146, 76-84. [CrossRef]

95. Lee, K.-W.; Kim, W.H.; Li, C.; Lillehoj, H.S. Detection of necrotic enteritis B-like toxin secreted by Clostridium perfringens using capture enzyme-linked immunosorbent assay. Avian Dis. 2020, 64, 490-495. [CrossRef]

96. Lee, K.W.; Lillehoj, H.S.; Kim, W.H.; Park, I.; Li, C.; Lu, M.; Hofacre, C.L. Research note: First report on the detection of necrotic enteritis (NE) B-like toxin in biological samples from NE-afflicted chickens using capture enzyme-linked immunosorbent assay. Poult. Sci. 2021, 100, 101190. [CrossRef]

97. Wickramasuriya, S.S.; Park, I.; Lee, Y.; Kim, W.H.; Przybyszewski, C.; Gay, C.G.; van Oosterwijk, J.G.; Lillehoj, H.S. Oral delivery of Bacillus subtilis expressing chicken NK-2 peptide protects against Eimeria acervuline infection in broiler chickens. Front. Vet. Sci. 2021, 8, 684818. [CrossRef] 